\title{
Perbandingan aktivitas antioksidan dan antosianin daging buah naga Hylocereus costaricensis dan sirup buah naga Hylocereus costaricensis
}

\author{
Titin Aryani ${ }^{*}$, Isnin Aulia Ulfah Mu'awanah ${ }^{2}$ \\ Universitas 'Aisyiyah Yogyakarta, Jalan Ringroad Barat No.63, Mlangi Nogotirto, Gamping, Area Sawah, \\ Nogotirto, Kec. Gamping, Kabupaten Sleman, Daerah Istimewa Yogyakarta 55592 \\ 1 titinaryanipurnama@gmail.com*; isnin aulia@gmail.com \\ *korespondensi penulis
}

\begin{abstract}
Abstrak
Salah satu upaya untuk mempertahankan mutu dan memperpanjang masa simpan dari buah naga adalah dengan mengolahnya menjadi sirup. Tujuan penelitian ini adalah mengetahui perbandingan aktivitas antioksidan dan antosianin pada daging buah dan sirup buah naga Hylocereus costaricensis. Penelitian ini merupakan penelitian eksperimen kuantitatif di laboratorium. Metode pengambilan sampel dilakukan dengan metode purposive sampling. Metode pengukuran aktivitas antioksidan menggunakan metode perendaman DPPH (1,1-Diphenyl-2-picryl Hidrazil) diukur serapan pada panjang gelombang $517 \mathrm{~nm}$. Metode pengukuran antosianin dilakukan dengan menggunakan Analisis kandungan antosianin dilakukan dengan metode pH Differential Method (Giusti et a.l, 2001). Hasil penelitian menunjukkan bahwa rata-rata aktifitas antioksidan pada daging buah naga Hylocereus costaricensis yang adalah $67,81 \%$ sedangkan pada sirup buah naga adalah $42,81 \%$. Adapun kadar antosianin pada daging buah naga Hylocereus costaricensis yang di adalah $88,70 \mathrm{mg} / 100 \mathrm{~mL}$ dan pada sirup buah naga adalah $43,15 \mathrm{mg} / 100 \mathrm{~mL}$. Dapat disimpulkan bahwa aktivitas antioksidan dan antosianin daging buah naga Hylocereus costaricensis menurun setelah diolah menjadi sirup.
\end{abstract}

Kata kunci: buah, sirup, Hylocereus costaricensis, aktifitas antioksidan, antosianin

\begin{abstract}
One effort to support and extend the shelf life of dragon fruit is by processing it into syrup. The purpose of this study was to study the interaction of antioxidants and anthocyanins in the flesh of Hylocereus costaricensis dragon fruit and syrup. This research is a quantitative experimental study in a laboratory. The sampling method is done by purposive sampling method. The method of measuring antioxidant activity using the DPPH (1,1-Diphenyl-2-picryl Hidrazil) immersion method was measured with a wavelength of $517 \mathrm{~nm}$. Anthocyanin measurement method is carried out using anthocyanin content analysis carried out by the $\mathrm{pH}$ Differential Method method (Giusti et al. 2001). The results showed that the average antioxidant activity in Hylocereus costaricensis dragon fruit was $67.81 \%$ while in dragon fruit syrup it was $42.81 \%$. While the levels of anthocyanin in dragon fruit Hylocereus costaricensis are at $88.70 \mathrm{mg} / 100$ $\mathrm{mL}$ and in dragon fruit syrup is $43.15 \mathrm{mg} / 100 \mathrm{~mL}$. Can reduce the fact of antioxidants and the flesh of dragon fruit Hylocereus costaricensis decreases after being processed into syrup.
\end{abstract}

Keywords: fruit, syrup, Hylocereus costaricensis, antioxidant activity, anthocyanin 


\section{PENDAHULUAN}

Buah naga merupakan tanaman yang belakangan ini banyak dikembangkan di Indonesia karena kaya akan beragam khasiat. Hal ini yang membuat buah naga banyak diburu wisatawan. Wisatawan di Yogyakarta banyak berburu buah naga di Kulon Progo, khususnya di Kawasan Pantai Glagah Indah, Temon, Kulonprogo. Kebun buah naga yang terdapat di kabupaten tersebut dikelola untuk wisatawan dan buahnya di pasarkan ke penadah.

Buah naga merah adalah tumbuhan berbuah sering ditemukan di kabupaten beriklim tropis. Pemanfaatan buah naga selain daging buahnya, ternyata kulit dari buah naga merah (Hylocereus polyrhizus) dapat diolah untuk produksi pangan, sebagai bahan dasar pembuatan kosmetik dan pewarna alami pada makanan. Hal ini dikarenakan kulit buah naga mengandung senyawa-senyawa yang diduga dapat bermanfaat sebagai antioksidan.

Jenis-jenis buah naga meliputi beberapa spesies, diantaranya Hylocereus costaricensis (buah naga dengan daging super merah), Selenicereus megalanthus (buah naga dengan kulit kuning daging putih), Hylocereus undatus (buah naga dengan daging putih), dan Hylocereus polyrhizus (buah naga dengan daging merah).

Menurut Wu et al. (2006) kulit buah naga memiliki keunggulan yaitu kaya polifenol dan merupakan sumber dari antioksidan. Aktivitas antioksidan pada kulit buah naga lebih tinggi dibanding dengan aktivitas antioksidan pada daging buah naga merah, maka dari itu berpotensi untuk dikembangkan menjadi sumber antioksidan yang alami. Hal ini kemudian sesuai dengan teori dari Wu et al., (2006) yang menyatakan bahwa aktivitas antioksidan kulit buah naga merah (Hylocereus polyrhizus) lebih tinggi dibandingkan dengan daging buah naga merah (Hylocereus polyrhizus).

Buah naga merah memiliki kandungan senyawa bioaktif yang sangat beragam dan bermanfaat bagi tubuh. Komponen bioaktif tersebut diantaranya adalah asam askorbat, betakaroten, antosianin dan terdapat serat pangan dalam bentuk pektin (Farikha et al., 2013). Kandungan antosianin dalam buah naga merah merupakan zat warna yang berperan untuk memberikan warna merah kebiruan sehingga berpotensi menjadi pewarna alami untuk pangan dan dapat dijadikan alternatif pengganti pewarna sintetis. Keberadaan antosianin yang terkandung dalam sirup buah naga merah juga memiliki sifat yang tidak stabil dan rentan mengalami kerusakan apabila terkena suhu yang tinggi akibat pemanasan. Proses pemanasan menimbulkan degradasi senyawa antosianin sehingga berubah menjadi keton, keton ini menyebabkan penurunan gugus hidroksi fenolik antosianin sebagai pendonor hidrogen 
radikal bebas, sehingga dapat berdampak pada penurunan kemampuan antosianin yang juga memiliki peran sebagai senyawa antioksidan (Apriyanto dan Frisqila, 2016).

Prior, dkk (1998) menyatakan aktivitas antioksidan antosianin lebih besar 2-6 kali dibandingkan antioksidan umum lain seperti asam askorbat dan glutation. Selain itu, banyak bukti menunjukkan bahwa senyawa ini mudah diserap oleh tubuh, berperan dalam perlindungan oksidatif, serta memainkan peranan penting untuk memerangi penyakit jantung maupun berbagai penyakit kanker (Smith, dkk. 2000).

Peran buah naga sebagai tanaman berkhasiat obat merupakan hal yang sudah banyak diyakini kebenarannya. Buah naga sangat berperan dalam membantu proses pencernaan, mencegah kanker colon dan diabetes, mengandung substansi yang mampu menetralisir racun (logam berat), menurunkan kadar kolesterol dan tekanan darah selain mencegah batuk dan asma. Tingginya kadar potassium, protein, fiber, sodium dan calcium merupakan kelebihan buah naga sebagai buah kesehatan dibandingkan buah buahan lainnya.

Karena peran yang begitu penting sebagai tanaman obat, maka kesegaran dan sedikitnya perubahan fisik serta biologisnya sangat diperlukan didalam proses pengolahan. Warna merah suatu sari buah mengindikasikan adanya kandungan antioksidan yang tinggi, oleh sebab itu, maka penggunaan warna alami dengan menggunakan kulit buah naga perlu dicoba dalam proses pembuatan sirup buah naga.

Salah satu upaya untuk mempertahankan mutu dan memperpanjang masa simpan dari buah naga merah adalah dengan mengolahnya menjadi sirup dengan cara menambahkan gula dengan konsentrasi tinggi untuk memperpanjang masa simpan dan meningkatkan mutu buah naga. Berdasarkan uraian tersebut, maka diperlukan penelitian tentang stabilitas kandungan gizi, fitokimia, dan organoleptik buah naga dan sirup buah naga merah agar dapat diketahui efektifitas pengolahan sirup. Berdasarkan beberapa penelitian tersebut diatas, diperlukan informasi kandungan aktifitas antioksidan dan antosianin pada daging dan sirup buah naga Hylocereus costaricensis agar dapat diketahui bagaimana perubahan aktivitas antioksidan dan antosianin buah naga Hylocereus costaricensis setelah diolah menjadi sirup.

\section{METODE}

\section{Alat dan Bahan}

Alat yang digunakan pada penelitian ini adalah alat-alat gelas, lampu cawan penguap, cawan porselen, desikator, oven, rotary, waterbath, dan Spektrofotometer UV-Vis. 
Bahan yang digunakan dalam penelitian ini meliputi buah naga dan sirup buah naga Hylocereus costaricensis, 1,1-difenil-2-pikrilhidrazil (DPPH) p.a, metanol p.a, asam askorbat (vitamin C), n-butanol p.a, asam asetat dan akuades.

\section{Prosedur Penelitian}

\section{Pembuatan Sirup buah Naga Hylocereus costaricensis}

Siapkan $300 \mathrm{ml}$ sari buah naga lalu ditambahkan 150 air untuk masing-masing perlakuan. Setelah itu siapkan gula sebanyak 50\% dari berat bahan yang telah ditambah air. Masukkan $450 \mathrm{ml}$ sari buah yang telah ditambah air kedalam panci, biarkan panas selama 5 menit, lalu setelah itu tambahkan gula yang telah disiapkan sesuai perlakuan, yaitu 50\%. Pada saat proses pemanasan, dilakukan pengadukan agar gula larut dan tercampur rata dengan sari buah naga merah. Saat gula telah larut lakukan pemanasan selama 15 menit pada suhu $50^{\circ} \mathrm{C}$ agar gula benar-benar tercampur rata, sambil ditambahkan 1/2 sendok teh gelatin. Setelah agak dingin tambahkan sebanyak 1 sendok teh perasa cocopandan.

\section{Pembuatan Ekstrak Metanol Daging dan Sirup Buah Naga Hylocereus costaricensis}

Sebanyak 500 g sampel daging buah naga Hylocereus costaricensis, dipotong kecil-kecil. Untuk pembuatan ekstrak dari sirup buah naga, dibutuhkan $500 \mathrm{~mL}$ sirup kemudian sampel daging buah dan syrup buah naga dimaserasi selama 3 hari menggunakan 4 L pelarut metanol. Setiap 24 jam, pelarut diganti dan dilakukan pengadukan sesering mungkin. Kemudian filtrat dipekatkan dengan vakum hingga diperoleh ekstrak.

\section{Pengukuran Absorbansi Peredaman Radikal Menggunakan Instrumen Spektrofotometer UV-Vis}

Uji aktivitas antioksidan dilakukan dengan metode DPPH (2,2-difenil-1-pikrilhidrazil) (Molyneux, 2004). Pengukuran dimulai dengan menambahkan sebanyak $1 \mathrm{~mL}$ ekstrak metanol daging buah dan sirup buah naga Hylocereus costaricensis dengan konsentrasi 50 $\mu \mathrm{g} / \mathrm{mL} .75 \mu \mathrm{g} / \mathrm{mL}, 100 \mu \mathrm{g} / \mathrm{mL}, 125 \mu \mathrm{g} / \mathrm{mL}$ dan $150 \mu \mathrm{g} / \mathrm{mL}$ kedalam 2 mL DPPH 0,1 mmol/L. Campuran tersebut kemudian dikocok hingga homohen. Setelah itu, campuran diinkubasi pada tempat gelap dengan suhu kamar selama 30 menit. Selanjutnya sampuran larutan ini diukur absorbansinya pada panjang gelombang $517 \mathrm{~nm}$. Perlakuan yang sama juga dilakukan untuk larutan blanko dan kontrol positif vitamin $\mathrm{C}$ dengan konsentrasi $2 \mu \mathrm{g} / \mathrm{mL}, 3 \mu \mathrm{g} / \mathrm{mL}, 4$ $\mu \mathrm{g} / \mathrm{mL}, 5 \mu \mathrm{g} / \mathrm{mL}$, dan $6 \mu \mathrm{g} / \mathrm{mL}$.

\section{Analisis Kandungan Antosianin Daging Buah dan Sirup Buah Naga Hylocereus costaricensis}


Analisis kandungan antosianin dilakukan dengan metode $\mathrm{pH}$ Differential Method (Giusti et a.l, 2001). Sejumlah volume tertentu dari ekstrak daging buah dan sirup buah naga Hylocereus costaricensis dilarutkan dalam dua larutan buffer yang berbeda. Larutan pertama dilarutkan dengan 0,025 $\mathrm{M}$ buffer $\mathrm{KCl} \mathrm{pH}$ 1,0 dan larutan lainnya dilarutkan dalam 0,4 M buffer natrium asetat $\mathrm{pH} 4,5$. Jumlah sampel yang digunakan diatur sehingga menghasilkan absorbansi pada panjang gelombang maksimum memberikan nilai absorbansi yang berada pada rentang linier dari spektrofotometer. Dilakukan pula scanning panjang gelombang pada rentang 200nm - $750 \mathrm{~nm}$ untuk larutan sampel pada kedua buffer ( $\mathrm{KCl}$ dan Natrium Asetat) untuk determinasi kandungan antosianin dan penentuan panjang gelombang maksimum pada saat pengukuran sampel. Selanjutnya dilakukan pengukuran absorbansi masing-masing larutan. Analisis kandungan antosianin pada penelitian ini dilakukan oleh tenaga ahli di Laboratorium Teknologi Pangan.

\section{HASIL DAN PEMBAHASAN}

Antioksidan merupakan senyawa pemberi elektron. Senyawa ini memiliki berat molekul yang kecil, namun mampu menghambat berkembangnya reaksi oksidasi dengan cara mencegahnya membentuk radikal bebas. Terdapat beberapa metode yang dapat digunakan untuk mengukur aktivitas antioksidan. Pada penelitian ini aktivitas antiokasidan diuji dengan metode DPPH. Metode uji DPPH (1,1-diphenylphikrihidraszyl) merupakan salah satu metode yang paling banyak digunakan untuk memperkirakan efektivitas kinerja dari substansi yang berperan sebagai antioksidan. Metode pengujian ini berdasarkan pada kemampuan substansi antioksidan tersebut dalam menetralisir radikal bebas. Pada penelitian ini, metanol dipilih sebagai pelarut pada saat pembuatan ekstrak karena metanol merupakan senyawa polar yang dapat melarutkan ekstrak daging buah naga Hylocereus costaricensis.

Radikal bebas DPPH merupakan radikal bebas yang stabil pada suhu kamar dan larut dalam metanol. Sifat stabil dikarenakan DPPH memiliki sebuah molekul yang didelokalisir dari molekul utuhnnya. Delokalisasi ini akan memberikan warna gelap dengan absorbansi maksimum pada panjang gelombang $517 \mathrm{~nm}$. Hal inilah yang mendasari pemilihan panjang gelombang saat pengukuran Absorbansi peredaman radikal menggunakan Spektrofotometer UV-Vis pada penelitian ini.

Metode aktivitas antioksidan menggunakan metode DPPH dipilih karena metode ini sederhana, cepat, peka, mudah dan hanya membutuhkan sedikit sampel. Metanol dipilih 
sebagai pelarut karena metanol dapat melarutkan kristal DPPH dan memiliki sifat yang dapat melarutkan komponen nonpolar didalamnya (Molyneux, 2004).

Perubahan warna dari ungu menjadi kuning sebagai absorptivitas molar radikal DPPH pada $517 \mathrm{~nm}$, ketika elektron tak berpasangan pada radikal DPPH berpasangan dengan atom hidrogen membentuk DPPH-H tereduksi. Perubahan tersebut dapat diukur dengan spektrofotometer UV-Vis dan dihubungkan terhadap konsentrasi. Penurunan intensitas warna yang terjadi disebabkan oleh berkurangnya ikatan rangkap terkonjugasi pada radikal DPPH berpasangan dengan hidrogen zat antioksidan menyebabkan tidak adanya kesempatan elektron tersebut beresonansi.

Selama proses pematangan, buah banyak terjadi perubahan kimia, termasuk perubahan komposisi pigmen dan perubahan warna yang melibatkan proses biosintesis dan katabolisme. Selama proses pematangan ini, kloroplas secara berangsur-angsur akan digantikan oleh kromoplas yang hanya mengandung karotenoid. Proses pematangan pada berbagai buah juga melibatkan biosintesis antosianin yang larut dalam air yang terakumulasi dalam vakuola sentral dalam sel mesofil. Proses pembentukan antosianin ini diawali oleh malonil-CoA yang berasal dari 3 asetil-CoA dan p-koumaroil-CoA fenilalanin (MacDougall 2002).

Ketika tingkat kematangan semakin tinggi maka aktivitas antioksidannya semakin tinggi, antosianin juga meningkat pada buah yang semakin matang. Berdasarkan penelitian ini, diperoleh hasil bahwa aktivitas antioksidan dan antosianin pada daging buah naga ditampilkan pada Tabel 1.

Tabel 1. Aktivitas Antioksidan dan antosianin Daging Buah Naga Hylocereus costaricensis

\begin{tabular}{|c|c|c|c|c|c|}
\hline No. & $\begin{array}{l}\text { Pengukuran } \\
\text { Ke- }\end{array}$ & $\begin{array}{c}\text { Hasil } \\
\text { Pengukuran } \\
\text { Aktivitas } \\
\text { Antioksidan } \\
\text { daging buah } \\
(\%)\end{array}$ & $\begin{array}{c}\text { Hasil } \\
\text { Pengukuran } \\
\text { Aktivitas } \\
\text { Antioksidan } \\
\text { sirup (\%) }\end{array}$ & $\begin{array}{c}\text { Kadar } \\
\text { antosianin } \\
\text { buah naga } \\
\text { (mg/100mL) }\end{array}$ & $\begin{array}{c}\text { Kadar } \\
\text { antosianin } \\
\text { sirup } \\
(\mathrm{mg} / 100 \mathrm{~mL})\end{array}$ \\
\hline 1 & $\begin{array}{c}\text { Pengukuran Ke- } \\
1\end{array}$ & 67,76 & 43,15 & 89,014 & 42,92 \\
\hline 2 & $\begin{array}{l}\text { Pengukuran Ke- } \\
2\end{array}$ & 68,51 & 42,92 & 89,034 & 42,28 \\
\hline 3 & $\begin{array}{c}\text { Pengukuran Ke- } \\
3\end{array}$ & 67,53 & 42,08 & 89,869 & 42,30 \\
\hline 4 & $\begin{array}{l}\text { Pengukuran Ke- } \\
4\end{array}$ & 67,45 & 43,10 & 89,889 & 42,36 \\
\hline & $\begin{array}{l}\text { ata-rata hasil } \\
\text { oengukuran }\end{array}$ & 67,81 & 43,81 & 89,451 & 43,15 \\
\hline
\end{tabular}




\section{SIMPULAN}

Aktivitas antioksidan daging buah naga Hylocereus costaricensis yang ditanam di Kulon Progo menghasilkan aktivitas antioksidan rata-rata sebesar $67,81 \%$ dan antosianin sebesar $89,451 \mathrm{mg} / 100 \mathrm{~mL}$.

\section{REFERENSI}

Apriyanto, D. R. dan C. Frisqila. 2016. Perbandingan Efektivitas Ekstrak dan Fermentasi Buah Naga Merah terhadap Penurunan Kadar Kolesterol Low Density Lipoprotein (LDL) pada Tikus Putih yang dibuat Hiperkolesterolemia.

Farikha, I. N., Choirul, A., \& Esti, W. 2013. Pengaruh Jenis dan Konsentrasi Bahan Penstabil Alami terhadap Karakteristik Fisikokimia Sari Buah Naga Merah (Hylocereus polyrhizus) Selama Penyimpanan. Jurnal Teknosains Pangan. 2 : 0733-2302.

MacDougall DB. 2002. Colour in Food: Improving Quality. CRC Press, Boca Raton. GómezPlaza E, Miñano A, dan López-Roca JM. 2006. Comparison of chromatic properties, stability and antioxidant capacity of anthocyanin-based aqueous extracts from grape pomace obtained from different vinification methods.

Molyneux P., 2004. The Use of Stable Free Radical Diphenylpicrylhydrazyl (DPPH) for Estimating Antioksidant Activity. Songklanakarin Journal Science and Technology. 26(2) : 211-219.

Nataliani, Maria Monasias, dkk. 2018. Pengaruh penyimpanan dan pemanasan terhadap Stabilitas Fisik dan Aktivitas Antioksidan Larutan Pewarna Alami Daging Buah Naga (Hylocereus costaricensis). 11(1):1-10. Jurnal Tumbuhan Obat Indonesia. Agustus 2018.

Prior, R.L., Cao, G., Martin A., Soffic E., McEwen J., O’Brien C., Lishchner N., Ehlenfeldt M., Kalt W., Krewer G., Mainland C.M., 1998. Antioxidant capacity as influenced by total phenolic and antochyanin content, maturity and variety of Vaccanium Spesies. Journal Agriculture Food Chemistry. 46 (7):2686-2693.

Smith, M.A.L., K.A. Marley, D. Seigler, K.W. Singletary and B. Meline. 2000. Bioactive properties of wild bluberry fruits. Journal Food Science. 65 (2): 352-356.

Wu, L. C., Hsu, H. W., Chen, Y., Chiu, C.C., and Ho, Y. I. 2006. Antioxidant and Antiproliferative Activities of Red Pitaya. Food Chemistry. Volume, 95: 319-327. 